\title{
Exogenously Applied Polyamines Reduce Reactive Oxygen Species, Enhancing Cell Division and the Shoot Regeneration from Brassica oleracea L. var. capitata Protoplasts
}

\author{
Agnieszka Kiełkowska *(D) and Adela Adamus
}

Department of Plant Biology and Biotechnology, Faculty of Biotechnology and Horticulture, University of Agriculture in Krakow, Al. 29-Listopada 54, 31-425 Krakow, Poland; a.adamus@urk.edu.pl

* Correspondence: a.kielkowska@urk.edu.pl; Tel.: +48-12-662-51-90

Citation: Kiełkowska, A.; Adamus, A. Exogenously Applied Polyamines Reduce Reactive Oxygen Species, Enhancing Cell Division and the Shoot Regeneration from Brassica oleracea L. var. capitata Protoplasts. Agronomy 2021, 11, 735. https:// doi.org/10.3390/agronomy11040735

Academic Editor: Alessandro Miceli

Received: 2 March 2021

Accepted: 7 April 2021

Published: 10 April 2021

Publisher's Note: MDPI stays neutral with regard to jurisdictional claims in published maps and institutional affiliations.

Copyright: (c) 2021 by the authors. Licensee MDPI, Basel, Switzerland. This article is an open access article distributed under the terms and conditions of the Creative Commons Attribution (CC BY) license (https:/ / creativecommons.org/licenses/by/ $4.0 /)$.

\begin{abstract}
Polyamines (PAs) are organic molecules that are found in plants and animals. In plants, they are involved in the regulation of cellular growth, apoptosis, rooting, flower development, and stress responses. The effect of exogenously applied polyamines on the development of Brassica oleracea L. var. capitata protoplast cultures was studied. Protoplasts were isolated from hypocotyls of 2-week-old seedlings of three accessions and they were cultured in liquid media supplemented with putrescine (Put), spermidine (Spd), and spermine (Spm) at concentrations of 0 (control), 10, 20, and $40 \mu \mathrm{M}$. In the very early culture (24 and $48 \mathrm{~h}$ ), cellular reactive oxygen species levels (ROS) in live cells were monitored using a fluorescent probe. The Put- and Spd-treated protoplasts exhibited lower fluorescence intensities, which corresponded to lower ROS accumulation as compared to the PA-free control. The protoplast viability was affected by the type of polyamine applied rather than its concentration. Put and Spd had a beneficial effect on the mitotic activity of the cultured cells, which was observed in all tested accessions. The highest frequency of shoot organogenesis (21\%) was obtained from microcalli derived from the protoplasts cultured on the medium supplemented with $10 \mu \mathrm{M}$ Put. Analysis of the ploidy level of the regenerants showed that the vast majority were diploids. Our results demonstrated that exogenously applied PAs maintained the viability of $B$. oleracea L. var. capitata protoplasts by alleviating oxidative stress and stimulating mitotic activity, which further affected the plant regeneration process.
\end{abstract}

Keywords: aliphatic amines; cabbage; fluorescent probe; hypocotyl; mitotic divisions; organogenesis; putrescine; ROS; spermidine; spermine; viability

\section{Introduction}

Genus Brassica includes many important agricultural and horticultural crops that are utilized as food, condiments, or oilseed crops. The significance of certain brassicas differs worldwide: Brassica oleracea L. including vegetables such as white/red cabbage (var. capitata f. sp. alba and rubra), cauliflower (var. botrytis), savoy (var. sabauda), brussel sprouts (var. gemmifera), kale (var. acephala), or broccoli (var. italica) are popular in Europe; Chinese cabbage (Brassica rapa ssp. pekinensis) and canola (Brassica napus L.) are cultivated mostly in Asia; turnip (B. rapa subsp. rapa L.) and canola are important in North America for oilseed production [1]. Recently, with the increasing awareness of the importance of diet for human health, much interest has been devoted to the nutritional values and medicinal (anti-cancer) properties of Brassica vegetables, with special attention being paid to cabbage, kale, and broccoli [2]. Breeding strategies highly depend on the market trends, which motivates the broadening of the existing genetic resources into new important traits via the integration of biotechnology and breeding programs [3]. Somatic hybridization (somatic fusion) is a powerful technique that allows for manipulating genomes via the fusion of protoplasts.

Protoplasts are the cells with the cell wall removed, which is accomplished with an enzymatic treatment [4]. Somatic fusion depends on many factors, e.g., the source of 
protoplast, isolation procedure, protoplast culture, fusion conditions, and regeneration. The usefulness of this method in crop improvement highly depends on the induction of sustained cell divisions during the culture and the ability of the cultured cells to regenerate into complete plants [5]. In the genus Brassica, the protoplast cultures have been most intensively studied in B. napus L. due to its high economic value, where the research has been mainly focused on the improvement of the fatty acids composition and disease resistance. In B. oleracea L. var. capitata, plant regeneration from protoplast-derived cells and somatic fusion has also been reported [6-9]. Although much effort has been devoted to the elaboration of efficient protocols for protoplast culture, plant regeneration is the main problem hindering the utilization of protoplast technology in practice. The ability of a single cell to regenerate into an organ (organogenesis) or embryo (embryogenesis) is a very complex process that depends on many factors, among which, the genotype of the protoplast donor plays a crucial role [4,6,9-11].

Polyamines (PAs) are low-molecular-weight aliphatic amines that are naturally present in both prokaryotes and eukaryotes [12] and are detected in the cytoplasm, cell wall, vacuole, mitochondria, and chloroplasts [13]. PAs are present in plants in amounts varying from micromolars to millimolars [14]. The most common PAs in plants are putrescine (Put, 1,4-diaminobutane), spermidine (Spd, 1,8-diamine-4azaoctane), and spermine (Spm, 1,12-diamine-4,9-triethylenetertramine). PAs are synthesized from amino acids through decarboxylation. The basic amino acids are arginine, lysine, methionine, and ornithine. Put is formed directly from ornithine (via the ODC pathway) or indirectly through a series of intermediates, i.e., arginine and agmatine (via the ADC pathway), while Spd and Spm are synthetized from Put [12-14]. PAs are present in plants as free amines; however, they can conjugate to hydroxycinnamic acids (HCAs), forming phenol amides [13]. Phenol amides produced in the phenylpropanoid pathway are secondary plant metabolites with antioxidant and antimicrobial properties. These compounds protect against biotic or abiotic stresses through an increase in the activity of various antioxidant enzymes and the regulation of osmolysis; they also prevent chlorophyll degradation and protect the cell membrane from peroxidation [15,16]. Moreover, PAs in general and Put in particular are considered to be nitrogen sources that have an anti-stress effect on stressed plants [14]. Free PAs can also covalently bind to acidic proteins, membrane phospholipids, and nucleic acid proteins or nucleic acids $[14,15]$. These PAs are associated with the regulation of enzyme activity, the stability of nucleic acids, DNA replication, gene transcription, cell division, and membrane stability $[17,18]$, and have an effect on the regulation of developmental and physiological processes, e.g., root growth, flower initiation, and fruit development [19-21].

PAs are also engaged in developmental processes under in vitro conditions. Exogenous PAs have a promotive effect on organogenesis from seedling explants of Brassica campestris L. [22] and B. oleracea L. [23], increasing shoot regeneration. Studies on somatic embryogenesis (SE) in Daucus carota L. showed that the PA content, especially Put, in highly embryogenic callus cultures significantly increased in comparison to non-embryogenic calli [24]. Additionally, in D. carota L., the inhibition of the primary enzyme for Put biosynthesis, namely, arginine decarboxylase (EC 4.1.1.19, ADC), arrested PA biosynthesis, which resulted in a significant $(50 \%)$ reduction in the development of somatic embryos [25]. The increased content of endogenous PAs was observed in somatic embryos of Vitis vinifera L. [26]. PAs were also important for gametic embryogenesis. In Nicotiana tabacum L., PA synthesis was necessary for embryo formation [27]. In the studies on gynogenesis in Allium cepa L., exogenous PAs (Spm and Spd) applied to the culture medium enhanced the embryo production from cultured ovules and increased callus production $[28,29]$. Conversely, exogenous Put, Spd, and Spm decreased the number of somatic embryos in Coffea canephora P. and Coffea arabica L. [30]. It has also been shown that cells undergoing division contain high levels of free PAs, while cells undergoing expansion and elongation contain low levels of free PAs [31]. During in vitro culture, PAs participate in key developmental processes that are mediated by specific signaling pathways or in cross-regulation with plant hormones [18,32]. 
In contrast, research on PA activity in protoplasts is relatively rare. Very early studies showed that ornithine, a precursor of Put, that was exogenously applied to protoplast cultures of Alnus spp. L. stimulated cell colony formation [33]. Exogenous Put and Spd resulted in increased incorporation of uridine in RNA in Avena sativa L. protoplasts, thus preventing senescence of protoplast-derived cells in the culture. In $V$. vinifera L. and $N$. tabacum L., the total endogenous Put predominated over Spd and Spm, and the highest accumulation of Put was observed in dividing protoplasts [34].

The expression of totipotency and the potential for the regeneration of plant protoplasts is a complex process that is affected by both genetic and environmental factors [34]. Protoplasts from cereals and legumes are recalcitrant and cannot regenerate, and protoplasts from tobacco or carrot regenerate easily, supporting their genetic background of totipotency [35]. Environmental factors, e.g., tissue wounding, nutrition medium composition, phytohormones, and light intensity and quality, also affect the process of reprogramming a somatic cell into a totipotent cell [36]. In our previous works, we have experienced a high level of recalcitrance to protoplast cultures from different accessions of Brassica oleracea $L .$, including cultivars and breeding lines $[7,8,37,38]$ that possess valuable traits in the context of somatic fusion. Therefore, we focused our efforts on searching for media supplements that can sustain protoplast viability and stimulate their further development, enabling complete plant regeneration.

In the present work, we addressed the hypothesis that PAs might be related to the expression of totipotency in B. oleracea L. protoplasts and that changing the endogenous homeostasis of biogenic amines via the external application of PAs will promote the expression of totipotency. To test these hypotheses, we applied selected PAs to the culture of calcium-alginate-immobilized B. oleracea L. var. capitata protoplasts and monitored their effect on the protoplast-derived cell viability, mitotic activity, and regeneration. Moreover, during the early culture, we tracked their effect on reactive oxygen species (ROS) production using a fluorescent probe. The ploidy level of the regenerants obtained as a result of the culture was verified using flow cytometry.

\section{Materials and Methods}

\subsection{Plant Material}

Seeds of Brassica oleracea L. var. capitata f. alba cultivar "Sława z Gołębiewa" (PlantiCo, Zielonki, Poland) and two breeding lines L203 and LLM (Polan, Krakow, Poland) were surface disinfected in $70 \%(v / v)$ ethanol for $2 \mathrm{~min}$, rinsed in $10 \%(w / v)$ chloramine $\mathrm{T}$ (Biochemie Poland, Katowice, Poland) for $20 \mathrm{~min}$, and washed three times in sterile distilled water for $5 \mathrm{~min}$. The seeds were placed in $9 \mathrm{~cm}$ Petri dishes with $30 \mathrm{~mL}$ of Murashige and Skoog (MS) media [39] macro- and microelements (Duchefa Biochemie, Haarlem, The Netherlands), supplemented with vitamins, $20 \mathrm{~g} / \mathrm{L}$ sucrose, and $2.5 \mathrm{~g} / \mathrm{L}$ Gelrite (Duchefa Biochemie, Haarlem, The Netherlands); the $\mathrm{pH}$ was adjusted to 5.7-5.8. The media was autoclaved $\left(20 \mathrm{~min}, 121^{\circ} \mathrm{C}, 0.1 \mathrm{MPa}\right)$. The seed cultures were kept in the dark at $25 \pm 2{ }^{\circ} \mathrm{C}$, and then, during the day of isolation, they were transferred into a room with dim light $\left(20 \mu \mathrm{mol} \mathrm{m} \mathrm{m}^{-2} \mathrm{~s}^{-1}\right)$ and a temperature of $25 \pm 2{ }^{\circ} \mathrm{C}$. Hypocotyl explants from germinated seeds that were approximately $6-8 \mathrm{~cm}$ in length were used for the protoplast isolation (Figure 1a).

\subsection{Protoplast Culture}

The hypocotyls were cut into small pieces with a scalpel (Figure 1b) and subjected to plasmolysis in 0.5 M mannitol (Sigma-Aldrich, Poznan, Poland) (pH 5.8) for $1 \mathrm{~h}$ at $25^{\circ} \mathrm{C}$ in the dark, as described before [7]. The tissue was further macerated in an enzyme solution consisting of $0.5 \%(w / v)$ cellulase Onozuka R-10 (Duchefa Biochemie, Haarlem, The Netherlands), 0.1\% (w/v) pectolyase Y-23 (Duchefa Biochemie, Haarlem, The Netherlands), $2 \mathrm{mM}$ of 2-(N-morpholino) ethanesulfonic acid (MES) (Sigma-Aldrich, Poznan, Poland), $3 \mathrm{mM} \mathrm{CaCl}_{2}$, and $0.4 \mathrm{M}$ mannitol ( $\mathrm{pH}$ 5.8) [38]. The enzyme solution was sterilized using a syringe filter (pore size $0.22 \mu \mathrm{m}$, Millipore, Durham, England). Maceration in the enzyme 
solution was done for $18 \mathrm{~h}$ at $25^{\circ} \mathrm{C}$ in the dark on a gyratory shaker (MPW-223e, MPW Med Instruments, Warsaw, Poland) (20 rpm). Then, the solution was filtered through a nylon sieve (pore size $100 \mu \mathrm{m}$, Millipore, Durham, England) and centrifuged at $101 \times g$ for $5 \mathrm{~min}$. The obtained pellets were resuspended in $0.5 \mathrm{M}$ sucrose with $1 \mathrm{mM}$ MES (Sigma-Aldrich, Poznan, Poland), overlaid with $2 \mathrm{~mL}$ of $\mathrm{W} 5$ salt solution, consisting of $154 \mathrm{mM} \mathrm{NaCl}, 125 \mathrm{mM} \mathrm{CaCl} 2 \cdot 2 \mathrm{H}_{2} \mathrm{O}, 5 \mathrm{mM} \mathrm{KCl}, 5 \mathrm{mM}$ glucose ( $\mathrm{pH}$ 5.8), as described by Menczel et al. [40], and centrifuged $(145 \times g, 10 \mathrm{~min})$. Protoplasts, which were localized in the interphase between sucrose/MES and the W5 solution (Figure 1c), were gently collected into a new tube, suspended in W5 solution, and centrifuged ( $101 \times g, 5 \mathrm{~min})$.
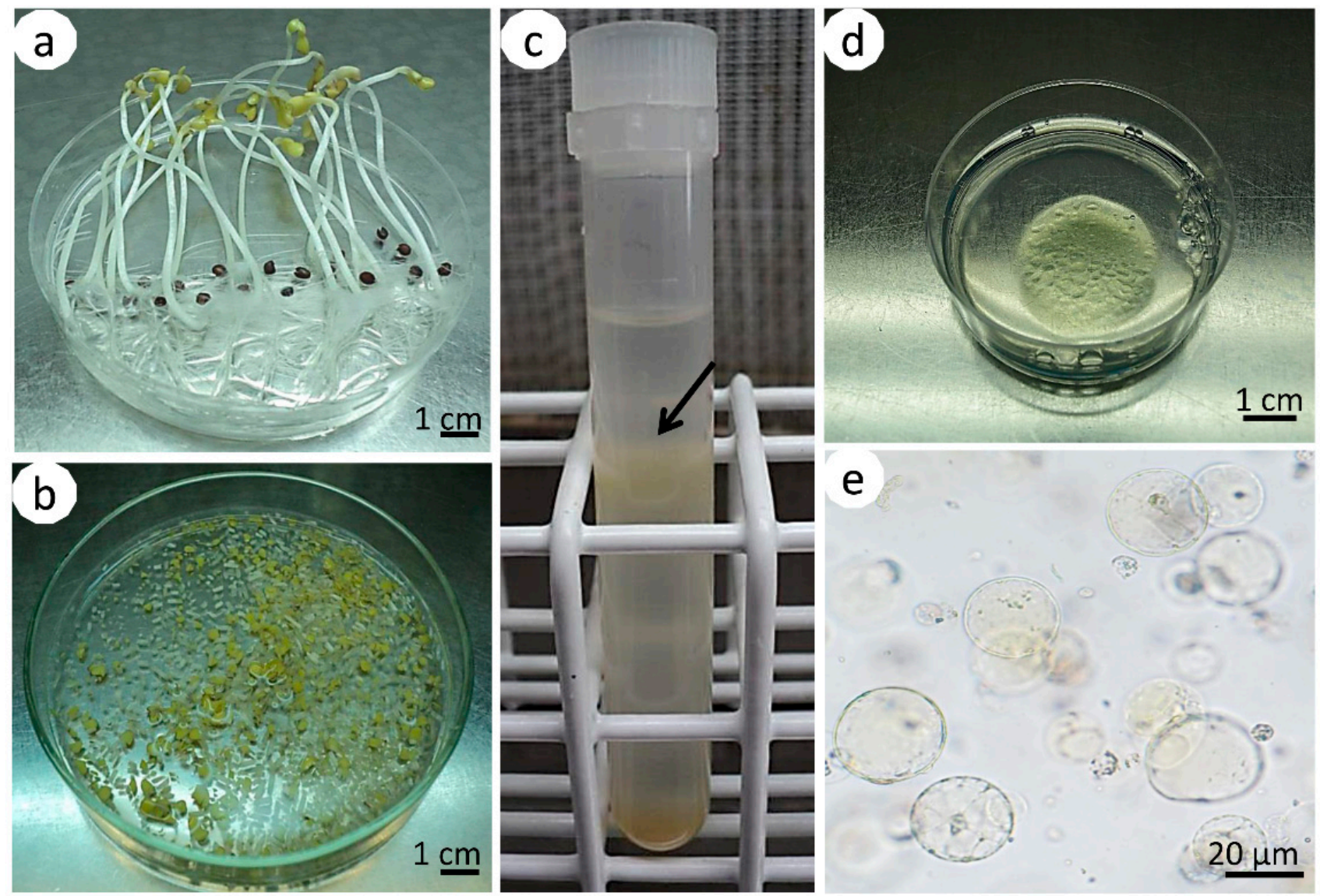

Figure 1. Isolation and immobilization of hypocotyl-derived protoplasts of Brassica oleracea L. var. capitata. Two-week-old, etiolated seedlings with elongated hypocotyls (a); fragmented hypocotyls subjected to plasmolysis (b); test tube with hypocotyl protoplasts gathered in a ring (arrow) between solutions of sucrose/2-(N-morpholino) ethanesulfonic acid (sucrose/MES) and W5 (c); Petri dish with an alginate layer with immobilized protoplasts (d); microscopic view of spherical protoplasts immobilized in an alginate layer (e).

Purified protoplasts were immobilized in filter-sterilized alginate according to the protocol of Kiełkowska and Adamus [8]. Briefly, equal volumes of protoplast suspension and alginate solution $(2.8 \%(w / v)$ alginic acid sodium salt (Sigma-Aldrich, Poznan, Poland), $0.4 \mathrm{M}$ mannitol, $\mathrm{pH} 5.8$, filter sterilized) were mixed to obtain a final culture density of $4 \times 10^{5} / \mathrm{mL}$. Alginate layers were obtained by spreading approximately $400 \mu \mathrm{L}$ of protoplast-alginate mixture with circular movements onto $60 \mathrm{~mm}$ Petri dishes containing calcium-agar media $\left(40 \mathrm{mM} \mathrm{CaCl}_{2}, 0.4 \mathrm{M}\right.$ mannitol, $1 \%(w / v)$ agar (Biocorp, Warsaw, Poland), pH 5.8, autoclaved (20 min, $\left.121^{\circ} \mathrm{C}, 0.1 \mathrm{MPa}\right)$. After $1 \mathrm{~h}$ of incubation at room temperature, the alginate polymerized to form solid layers with embedded protoplasts (Figure 1d,e). The discs with immobilized protoplasts were transferred to $60 \mathrm{~mm}$ Petri dishes containing $4 \mathrm{~mL}$ culture medium and sealed with parafilm. The culture 
medium consisted of macro- and microelements, and organic acids according to Kao and Michayluk [41]: B5 media vitamins [42], $250 \mathrm{mg} / \mathrm{L}$ casein hydrolysate (Sigma-Aldrich, Poznan, Poland), $74 \mathrm{~g}$ /L glucose, $0.45 \mu \mathrm{M}$ 2,4-dichlorophenoxyacetic acid (2,4-D), and $1 \mu \mathrm{M}$ zeatin ( $\mathrm{pH}$ adjusted to 5.6). The medium was filter-sterilized (pore size $20 \mu \mathrm{m}$, Millipore, Durham, England).

The culture media was supplemented with different concentrations $(10,20$, and $40 \mu \mathrm{M})$ of the following PAs (Sigma-Aldrich, Poznan, Poland): putrescine dichydrochloride (Put), spermidine (Spd), and spermine ( $\mathrm{Spm}$ ). A PA-free medium was used as control. Cultures were incubated in the dark at $25 \pm 2{ }^{\circ} \mathrm{C}$. The culture media for all treatments was renewed once after 10 days of culture. The medium used for the replacement did not contain PAs.

The cell viability of the cultured protoplasts was estimated on the first and fifth day after the protoplast isolation by staining with fluorescein diacetate (FDA, Sigma-Aldrich, Poznan, Poland). First, a stock solution $(3 \mathrm{mg} / \mathrm{mL})$ of FDA in acetone was prepared. Then, the stock solution was syringe-filtered $(0.22 \mu \mathrm{m}$, Millipore, Durham, England $)$ and frozen at $-20{ }^{\circ} \mathrm{C}$. A working solution was prepared by dissolving $60 \mu \mathrm{L}$ of stock solution in $4 \mathrm{~mL}$ of the culture media. Then, $50 \mu \mathrm{L}$ of the working solution was added to the Petri dishes with protoplasts. The dishes were incubated at room temperature in the dark for at least $15 \mathrm{~min}$ before observation. The frequency of the protoplast-derived cells' division was observed on the fifth and fifteenth days of culture. The observations of cell viability and mitotic activity were done under an Axiovert S100 inverted microscope (Carl Zeiss, Göttingen, Germany) supplied with an HBO50 mercury lamp and necessary filter set $\left(\lambda_{\mathrm{Ex}}=485 \mathrm{~nm}\right.$, $\left.\lambda_{\mathrm{Em}}=515 \mathrm{~nm}\right)$.

\subsection{Staining for Reactive Oxygen Species Accumulation}

The ROS levels in the protoplasts were evaluated 24 and $48 \mathrm{~h}$ after isolation by staining them with the fluorescent probe $2^{\prime}, 7^{\prime}$-dichlorodihydrofluorescein diacetate $\left(\mathrm{H}_{2} \mathrm{DCFDA}\right.$; Sigma-Aldrich, Poznan, Poland). A working solution of $\mathrm{H}_{2}$ DCFDA was prepared by dissolving the powdered reagent in $96 \%$ ethanol and placing it in light-protected Eppendorf tubes on ice. The working solution of $\mathrm{H}_{2}$ DCFDA was applied to the Petri dishes to achieve a final concentration of $1.0 \mu \mathrm{M}$. In this experiment we used protoplasts of two accessions: L203 and "Sława z Gołębiewa." $\mathrm{H}_{2}$ DCFDA was applied to the Petri dish containing PA-treated and control-immobilized protoplasts. The cultures were then incubated after approximately $1 \mathrm{~h}$ at room temperature in the dark. For the positive control, PA-free cultures were treated with $100 \mu \mathrm{M}$ hydrogen peroxide $\left(\mathrm{H}_{2} \mathrm{O}_{2}\right)$ and stained with $\mathrm{H}_{2}$ DCFDA. As a negative control, we used protoplasts maintained in the growth medium without the PA treatment or $\mathrm{H}_{2}$ DCFDA staining. The culture controls were PA-free cultures that were stained with $\mathrm{H}_{2}$ DCFDA. All cultures were subsequently imaged using an inverted microscope Axiovert S100 with Axiovision software (Carl Zeiss, Göttingen, Germany). Observations of fluorescence were done with the same filter set as for the viability observations. The exposure time for all images was the same. The images were analyzed using ImageJ software (National Institutes of Health, Bethesda, MD, USA). Total cell fluorescence intensity was calculated using the formula (cell area $\times$ cell mean fluorescence $)-($ cell area $\times$ mean fluorescence of the background $)$ and expressed in arbitrary units (a.u.).

\subsection{Callus Production and Plant Regeneration}

After four weeks of culture, each dish with protoplast-derived callus colonies was observed under a stereomicroscope (Leica S6D, Leica Microsystems, Wetzlar, Germany). Callus clumps that were approximately $0.5 \mathrm{~mm}$ in size and larger were counted, and afterward, the cultures were subjected to regeneration. Colonies of protoplast-derived calli were freed from the alginate layers according to the protocol of Damm and Willmitzer [43] and transferred to $90 \mathrm{~mm}$ Petri dishes containing $30 \mathrm{~mL}$ of MS2 medium consisting of MS macroand microelements, vitamins, $8.8 \mu \mathrm{M}$ 6-benzyladenine (BA), $2.7 \mu \mathrm{M}$ 1-napthaleneacetic acid (NAA), $20 \mathrm{~g} / \mathrm{L}$ sucrose, and $2.5 \mathrm{~g} / \mathrm{L}$ Gelrite (Duchefa Biochemie, Haarlem, The Nether- 
lands). The $\mathrm{pH}$ of the medium was adjusted to 5.7-5.8. The medium was autoclaved (20 min, $121^{\circ} \mathrm{C}, 0.1 \mathrm{MPa}$ ).

The shoots that developed from calli cultured on MS2 medium were transferred for further development to an MS hormone-free medium. The cultures, calli, and shoots were transferred to the appropriate fresh media every 3-4 weeks and were maintained at $25 \pm 2{ }^{\circ} \mathrm{C}$ with a $16 \mathrm{~h}$ photoperiod at a light intensity of $55 \mu \mathrm{mol} \mathrm{m}{ }^{-2} \mathrm{~s}^{-1}$.

\subsection{Flow Cytometry Analyses of the Regenerants}

The ploidy level of the regenerants was estimated using flow cytometry. The nuclei were released from tissues according to Kiełkowska et al. [44] with a minor modification, namely, the omission of polyvinylpyrolidone. Briefly, approximately $500 \mathrm{mg}$ of leaf tissue from in-vitro-cultured plants was cut with a razor blade in the presence of $1 \mathrm{~mL}$ of a lysis buffer ( $10 \mathrm{mM}$ Tris, $2 \mathrm{mM} \mathrm{MgCl} 2 \cdot 6 \mathrm{H}_{2} \mathrm{O}, 50 \mathrm{mM}$ sodium chloride, $0.1 \%(v / v)$ TRITON X-100, $\mathrm{pH}$ 7.0). The lysis buffer was supplemented with a $1 \mathrm{~mL} \mathrm{4',6-diamidino-2-phenylindole}$ dihydrochloride (DAPI, Sigma-Aldrich, Poznan, Poland) solution (10 mg DAPI in $10 \mathrm{~mL}$ of water). Then, the suspension was filtered through a nylon filter (pore size $30 \mu \mathrm{M}$, Millipore, Durham, England), incubated for $5 \mathrm{~min}$ at room temperature, and measured for the relative nuclear DNA content using Partec PA II (Partec GmbH, Münster, Germany). Leaves of the diploid ( $2 n=2 x=18$ ) cabbage cv. "Kamienna Głowa" (PlantiCo, Zielonki, Poland) were used as a reference standard. The ploidy was determined by comparing the position of the peak of the diploid standard with the position of the peak corresponding to the G1 nuclei of the regenerants.

\subsection{Data Collection and Statistical Analyses}

Each treatment (accession $\times$ PA type $\times$ PA concentration and controls) was represented using a minimum of five Petri dishes. The experiment was repeated three times. The viability was calculated as the number of protoplasts exhibiting green fluorescence per total number of observed cells $(\times 100)$. The frequency of division of protoplast-derived cells was calculated as the number of cells undergoing division and cell aggregates per total number of observed cells $(\times 100)$. The regeneration frequency was calculated as the number of shoots developed from a callus per total number of calli cultured on the regeneration media $(\times 100)$. The observations of cell viability and cell divisions were gathered from two Petri dishes from each treatment in each repetition. Analyses of the collected data were performed using an analysis of variance (ANOVA) module. Mean separation was done using Tukey's honestly significant difference test (HSD). The total cell fluorescence intensity results were analyzed using an ANOVA module, and the mean separation was done according to Duncan's multiple range test (MRT). All statistics were calculated with Statistica ver. 13.3 (TIBCO Software Inc., Palo Alto, CA, USA) software at a 0.05 probability level. The data are presented as a mean \pm standard error (SE).

\section{Results}

\subsection{ROS Detection in Protoplasts}

The staining of the living protoplasts of cabbage with $\mathrm{H}_{2}$ DCFDA was used to visualize and evaluate the ROS accumulation (Figure 2). The mode of action of $\mathrm{H}_{2}$ DCFDA during the detection of ROS accumulation was based on its chemical reduction and oxidation within the cell. Nonfluorescent $\mathrm{H}_{2}$ DCFDA diffuses through the cell membrane and enters the cell. Intracellular esterases cause the deacetylation of $\mathrm{H}_{2}$ DCFDA, which results in the generation of nonfluorescent $2^{\prime}, 7^{\prime}$-dichlorofluorescin $\left(\mathrm{H}_{2} \mathrm{DCF}\right) . \mathrm{H}_{2} \mathrm{DCF}$ is then oxidized by cellular ROS to create the fluorescent compound $2^{\prime}, 7^{\prime}$-dichlorofluorescein (DCF). The fluorescence intensity is directly proportional to the amount of DCFDA that has oxidized into DCF [45].

The detection of ROS was performed at two time points, namely, 24 and $48 \mathrm{~h}$ after isolation, for the two accessions, three tested PAs in three concentrations, and in controls (Figure 3). We did not observed differences in the ROS accumulation between the tested 
accessions $(p=0.15)$. In the positive control, the ROS accumulation was the highest and it was similar in both tested periods (Figures $2 \mathrm{a}$ and 3 ). In the negative control, the fluorescence intensities were very low, and the detected signals were most likely caused by chlorophyll autofluorescence (Figures $2 \mathrm{~b}$ and 3 ).
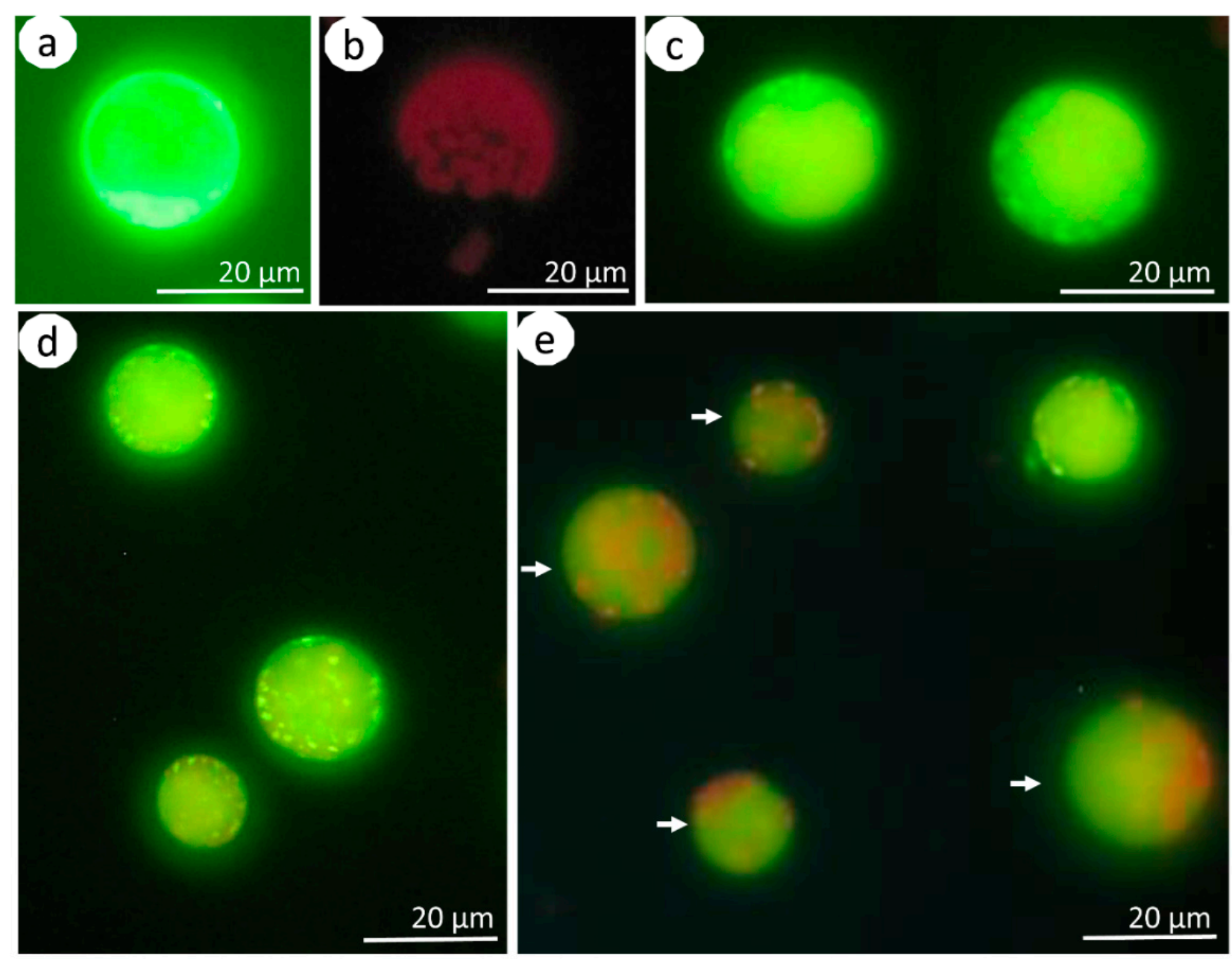

Figure 2. Protoplasts of Brassica oleracea L. var. capitata stained with $\mathrm{H}_{2}$ DCFDA and in controls. Positive control (cell from the $\mathrm{H}_{2} \mathrm{O}_{2}$-treated culture) (a); negative control (cell from the culture without any treatment) (b); exemplary view of polyamine-treated cells $24 \mathrm{~h}$ after isolation (c). Protoplast cultures that were treated with $10 \mu \mathrm{M}$ of Put after 24 (d) and 48 (e) hours of culture. The arrows in subfigure (e) mark the cells with yellow-green fluorescence of the cytoplasm with red signals breaking through from the chloroplasts.

In general, the Put- and Spd-treated cabbage protoplasts produced less ROS than the PA-free controls (culture control) (Figure 3). The ROS accumulation decreased with culture duration, as evidenced by the higher fluorescence intensities observed in protoplasts on the first day of culture compared to the second day $(p=0.00)$. The highest reduction of ROS accumulation for the tested time points was observed in cultures treated with 10 and $20 \mu \mathrm{M}$ Put and 20 and $40 \mu \mathrm{M}$ Spd. The ROS accumulation in Spm-treated cultures was higher than in the control cultures. In general, the fluorescence signals in PA-treated protoplasts $24 \mathrm{~h}$ after isolation were mainly localized in the cytosol and chloroplasts (Figure 2c,d). Signals in the cytosol were still detectable $48 \mathrm{~h}$ after isolation. However, the chloroplasts did not emit yellow-green fluorescence (Figure 2e), and we observed red signals, which were most likely coming from the autofluorescence of chlorophyll in the chloroplasts. 


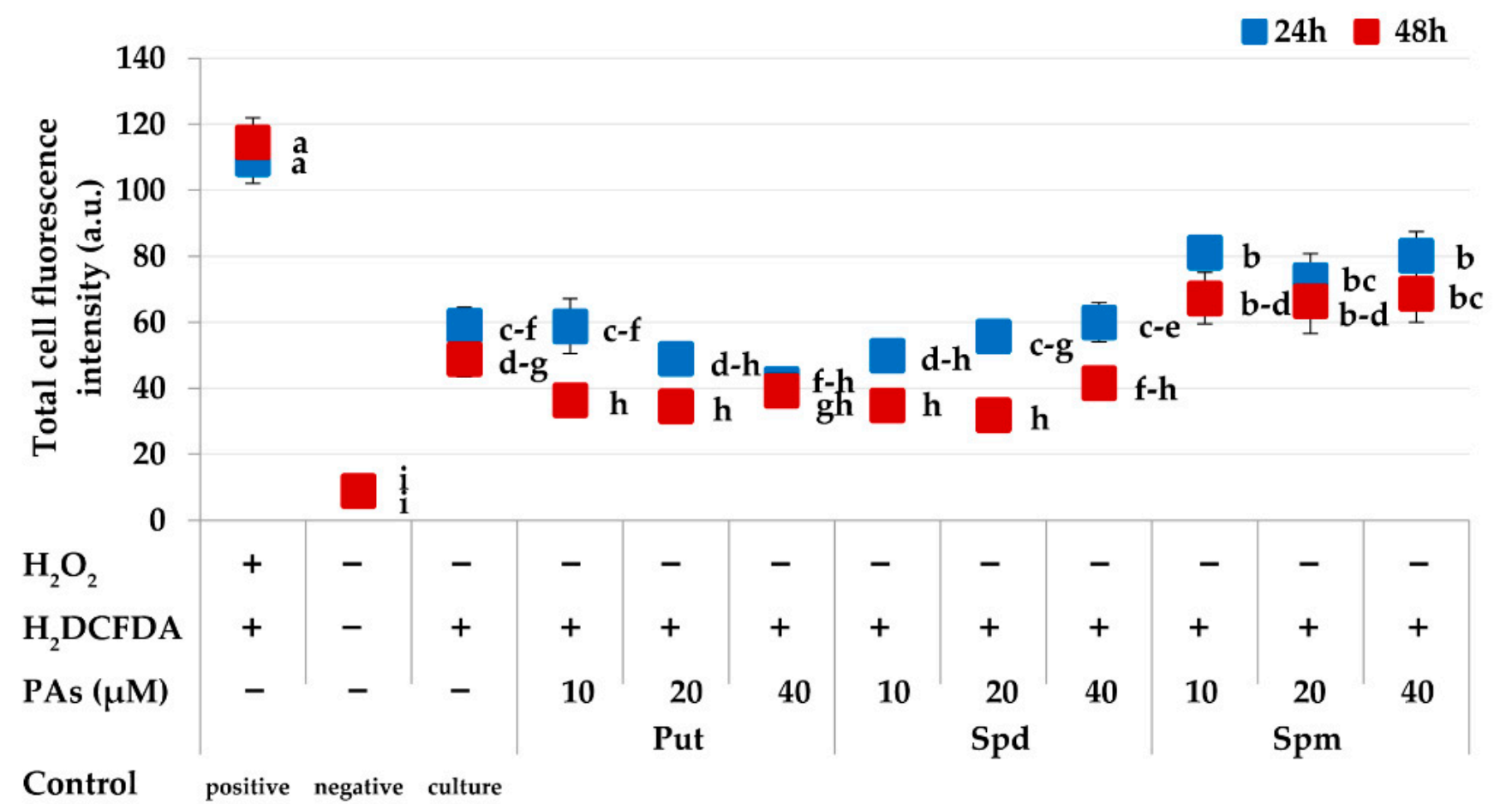

Figure 3. Detection of reactive oxygen species (ROS) in Brassica oleracea L. var. capitata protoplast cultures using $\mathrm{H}_{2} \mathrm{DCFDA}$. Measurements were based on the quantification of the fluorescence intensity. The points represent the means \pm SE $(n=80)$. The green and red points should be considered separately. Means followed by the same letter were not significantly different $(p \leq 0.05$, Duncan's multiple range test (MRT)). Description of the $x$-axis: " +" means the treatment was applied "-" means no treatment. The polyamines (PAs) are as follows: putrescine (Put), spermidine (Spd), and spermine (Spm).

\subsection{Viability of Protoplasts}

On the first day of culture, the protoplasts were spherical with dense cytoplasm (Figure 4a). On the fifth day of culture, few-celled aggregates were observed (Figure 4b). The viable protoplasts exhibited green fluorescence under UV light (Figure 4c,d) in both tested periods. There were no differences in protoplast viability among the tested accessions (Table 1). In both tested periods, the viability was high: near $92 \%$ on day one, and from $73.2 \%$ to $76.3 \%$ on the fifth day of culture. The exogenously applied PAs affected the viability of the protoplasts; however, differences were more distinguishable in the latter culture. On the fifth day, the viability of the protoplasts cultured on the PA-free control media was $69.4 \%$. Similar viability $(59.2-60.5 \%)$ was observed in protoplasts cultured on the medium supplemented with Spm for all concentrations. At the same time, the viability of the protoplasts cultured on the media supplemented with both Put and Spd was higher at $78.6-79.9 \%$ and $82.8-90.9 \%$, respectively.

\subsection{Mitotic Activity of the Protoplast-Derived Cells}

The first mitotic divisions of the cultured cells were observed after the third day in the cultures of all tested accessions. On the fifth day of culture, $7.5-11.1 \%$ of cells underwent division (Table 2). On the fifteenth day of culture, the highest number of dividing cells $(48.3 \%)$ was scored in cv. "Sława z Gołębiewa." There were no differences in the division frequency between the two remaining breeding lines, and in those accessions, $26.3-27.6 \%$ of the cultured cells underwent divisions. 


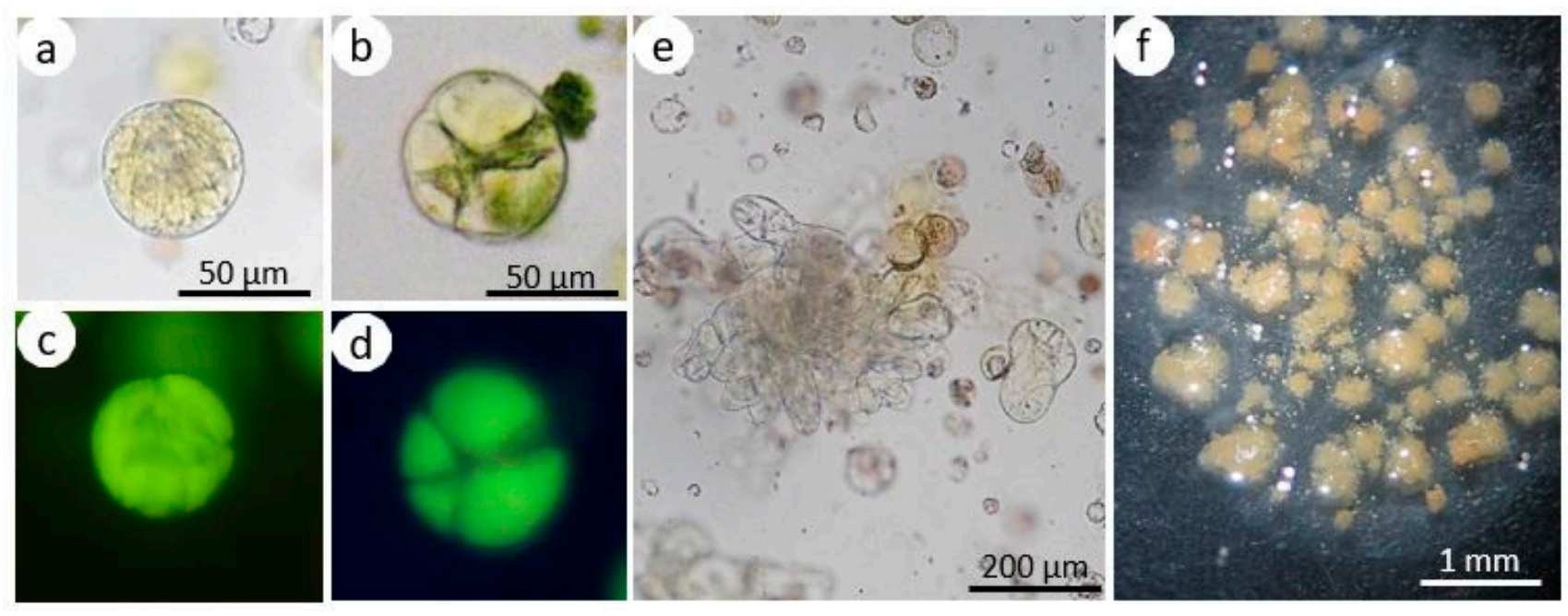

Figure 4. Culture of hypocotyl-derived protoplasts of Brassica oleracea L. var. capitata. Fluorescein diacetate (FDA)-stained protoplast culture on the first $(\mathbf{a}, \mathbf{c})$ and fifth day $(\mathbf{b}, \mathbf{d})$ visible in white light $(\mathbf{a}, \mathbf{b})$ and under UV light (c, d). The upper and lower pictures show the same view. Multicell aggregate (e); alginate layer overgrown with callus colonies (f).

Table 1. Mean effect of the accession and exogenous putrescine (Put), spermidine (Spd), and spermine (Spm) on the viability of the protoplast-derived cells of Brassica oleracea L. var. capitata. The values are the means \pm SE $(n=60)$. The data in columns denoted with the same letter were not significantly different ( $p \leq 0.05$, Tukey's honestly significant difference test (HSD)).

\begin{tabular}{ccc}
\hline Factor & \multicolumn{2}{c}{$\begin{array}{c}\text { Cell Viability (\%)(mean } \pm \text { SE) } \\
\text { Fifth Day }\end{array}$} \\
\hline Accession: & & \\
Sława zay & $73.8 \pm 0.9^{\mathrm{a}}$ \\
L203 & $91.9 \pm 0.5^{\mathrm{a}}$ & $73.2 \pm 1.0^{\mathrm{a}}$ \\
LLM & $91.9 \pm 0.5^{\mathrm{a}}$ & $76.3 \pm 2.0^{\mathrm{a}}$ \\
\hline Polyamines $(\mu \mathrm{M}):$ & $91.5 \pm 0.4^{\mathrm{a}}$ & \\
Control & & $69.4 \pm 1.1^{\mathrm{cd}}$ \\
Put 10 & $91.4 \pm 0.6^{\mathrm{ab}}$ & $78.8 \pm 1.3^{\mathrm{b}}$ \\
Put 20 & $88.0 \pm 1.2^{\mathrm{b}}$ & $79.9 \pm 1.7^{\mathrm{b}}$ \\
Put 40 & $90.2 \pm 0.8^{\mathrm{ab}}$ & $78.6 \pm 1.8^{\mathrm{bc}}$ \\
Spd 10 & $93.5 \pm 0.7^{\mathrm{a}}$ & $82.8 \pm 1.3^{\mathrm{ab}}$ \\
Spd 20 & $92.5 \pm 1.0^{\mathrm{a}}$ & $83.0 \pm 1.3^{\mathrm{ab}}$ \\
Spd 40 & $91.6 \pm 0.8^{\mathrm{ab}}$ & $90.9 \pm 6.1^{\mathrm{a}}$ \\
Spm 10 & $93.2 \pm 0.7^{\mathrm{a}}$ & $59.2 \pm 1.4^{\mathrm{d}}$ \\
Spm 20 & $94.4 \pm 0.7^{\mathrm{a}}$ & $60.4 \pm 1.5^{\mathrm{d}}$ \\
Spm 40 & $91.1 \pm 1.0^{\mathrm{ab}}$ & $60.5 \pm 1.5^{\mathrm{d}}$ \\
\hline
\end{tabular}

The exogenously applied PAs affected the division of the protoplast-derived cabbage cells. On the fifth day of culture, $7.0 \%$ of cells cultured on the control medium underwent mitotic division. At the same time, a higher division frequency (15.2-15.8\%) was observed on the media supplemented with 10 and $20 \mu \mathrm{M}$ Put. On the media supplemented with Spd, the division frequency ranged from 10.3 to $13.3 \%$. In cultures supplemented with Spm, the division frequency was the lowest for all concentrations (2.3-4.6\%). The division frequency increased with the culture time, and on the 15th day, the highest mitotic activity $(40.8-44.4 \%)$ was observed in protoplast-derived cells that were cultured on the media supplemented with 10 and $20 \mu \mathrm{M}$ Put and $20 \mu \mathrm{M}$ Spd. The mitotic activity of cells cultured on the remaining media ranged from 28.2 to $34.3 \%$ and was similar to that of the control media $(29.2 \%)$. 
Table 2. Mean effect of accession and exogenous putrescine (Put), spermidine (Spd), and spermine (Spm) on the division frequency of protoplast-derived cells of Brassica oleracea L. var. capitata. The values are the means \pm SE $(n=60)$. The data in columns denoted with the same letter were not significantly different $(p \leq 0.05$, HSD).

\begin{tabular}{|c|c|c|}
\hline \multirow{2}{*}{ Factor } & \multicolumn{2}{|c|}{ Division Frequency $(\%)($ mean \pm SE) } \\
\hline & 5th Day & 15th Day \\
\hline \multicolumn{3}{|l|}{ Accession: } \\
\hline Sława z Gołębiewa & $11.1 \pm 0.6^{\mathrm{a}}$ & $48.3 \pm 1.0^{\mathrm{a}}$ \\
\hline L203 & $7.5 \pm 0.5^{c}$ & $26.3 \pm 1.1^{b}$ \\
\hline LLM & $9.3 \pm 0.6^{\mathrm{b}}$ & $27.6 \pm 1.1^{b}$ \\
\hline \multicolumn{3}{|l|}{ Polyamines $(\mu \mathrm{M})$ : } \\
\hline Control & $7.0 \pm 0.6^{\mathrm{cd}}$ & $29.2 \pm 1.5^{\mathrm{c}}$ \\
\hline Put 10 & $15.8 \pm 1.2^{\mathrm{a}}$ & $43.0 \pm 2.4^{\mathrm{a}}$ \\
\hline Put 20 & $15.2 \pm 1.6^{\mathrm{a}}$ & $40.8 \pm 2.2^{\mathrm{ab}}$ \\
\hline Put 40 & $10.3 \pm 1.1^{\mathrm{bc}}$ & $30.8 \pm 2.3^{c}$ \\
\hline Spd 10 & $10.3 \pm 1.0^{b c}$ & $29.0 \pm 2.2^{\mathrm{c}}$ \\
\hline Spd 20 & $13.3 \pm 1.1^{\mathrm{ab}}$ & $44.4 \pm 2.6^{\mathrm{a}}$ \\
\hline Spd 40 & $10.0 \pm 0.8^{b c}$ & $34.3 \pm 1.9^{b c}$ \\
\hline Spm 10 & $4.6 \pm 0.8^{\text {de }}$ & $31.9 \pm 1.9^{c}$ \\
\hline Spm 20 & $4.0 \pm 0.6^{\mathrm{de}}$ & $28.2 \pm 1.5^{\mathrm{c}}$ \\
\hline Spm 40 & $2.3 \pm 0.4^{\mathrm{e}}$ & $29.9 \pm 1.4^{\mathrm{c}}$ \\
\hline
\end{tabular}

The effect of the interaction between the tested factors on the division frequency of protoplast-derived cells was also observed (Figure 5). On the 15th day of culture, in cv. "Sława z Gołębiewa," the protoplast-derived cells divided the most frequently on the medium supplemented with Put and Spd (53.2-57.1\%), regardless of the applied concentration. The cells cultured on the medium supplemented with Spm divided with a frequency of $38.1-44.1 \%$, which was similar to that of the control medium (37.5\%). The protoplast-derived cells of line L203 divided frequently $(41.6 \%)$ on the medium supplemented with $20 \mu \mathrm{M}$ Spd. Lower mitotic activity (28.7-34.0\%) was observed on the media with 10 and $20 \mu \mathrm{M}$ Put. The cells of this accession cultured on the medium supplemented with Spm divided with a similar frequency (23.0-27.7\%) to that of the cells cultured on the control medium $(29.2 \%)$. The highest frequency of cell division $(44.7 \%)$ was observed in the breeding line LLM in protoplast-derived cells cultured on the medium supplemented with $10 \mu \mathrm{M}$ Put. A higher concentration of this PA decreased the mitotic activity. Protoplast-derived cells of breeding line LLM cultured on the media supplemented with the tested concentrations of Spm divided with similar frequencies (22.9-28.6\%) to the cells cultured on the control medium $(27.4 \%)$.

\subsection{Callus Production and Shoot Regeneration}

Continuous mitotic divisions of the protoplast-derived cells, which were observed in the subsequent days of culture, lead to the formation of cell aggregates (Figure 4e) and later to the development of multi-cell colonies that were visible with the naked eye near the fourth week of culture (Figure $4 \mathrm{f}$ ). The mean number of callus clumps produced per single dish did not depend on the accession; however, it was affected by the type of PA and its concentration (Figures $6 \mathrm{a}$ and 7). In the cultures supplemented with 10 and $20 \mu \mathrm{M}$ Put, 32-34 callus clumps per single dish were produced. In the cultures treated with the highest concentration of this PA, 26 calli per dish were observed on average. On the media supplemented with Spm, the callus production was from 11 to 13 calli per dish.

Colonies were freed from the alginate layers and transferred to the solid regeneration media. After 4-6 weeks of culture on the regeneration medium, some of the callus clumps increased in size and became greenish; however, some clumps changed their color to brown and did not develop further. During the subsequent passages to the fresh regeneration media, shoot (Figure $6 \mathrm{~b}$ ) and root (Figure $6 \mathrm{c}$ ) organogenesis were observed. The shoots 
were much easier to regenerate into plants (Figure 6d) from callus clumps that were green and not covered with roots. The shoot regeneration from callus clumps covered with multiple whitish roots was not successful.

Shoot organogenesis was observed in all tested accessions with various frequencies (Table 3). The highest frequency of shoot development from protoplast-derived cells was noted for cv. "Sława z Gołębiewa" (4.7\%), lower in line LLM (2.8\%) and the lowest in line L203 (1\%).

Sława z Gołębiewa $\quad$ L203 nLM

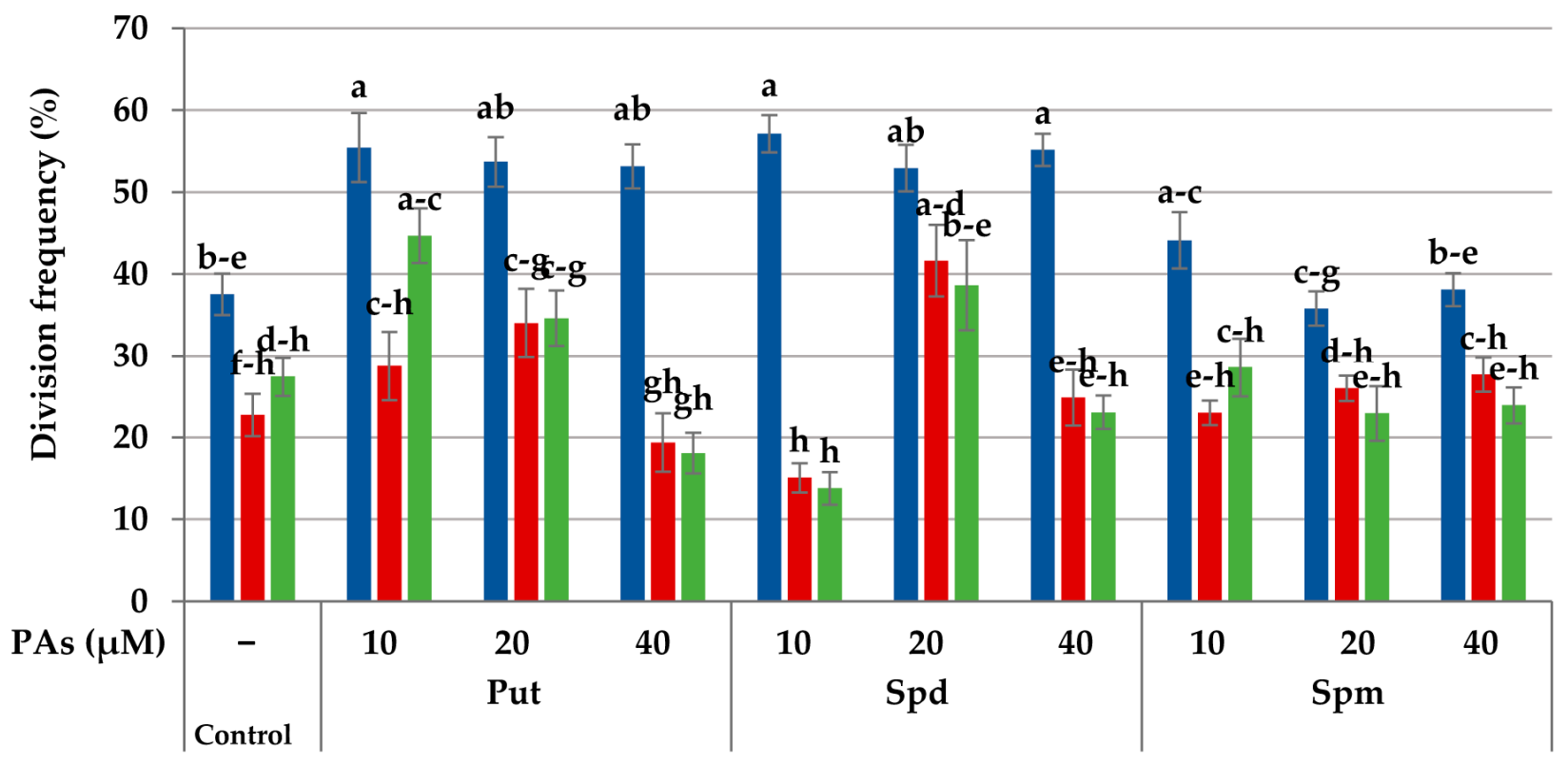

Figure 5. Interaction of the accession and exogenous putrescine (Put), spermidine (Spd), and spermine (Spm) on the division frequency of the protoplast-derived cells of Brassica oleracea L. var. capitata on the 15th day of culture. The bars represent the means \pm SE $(n=60)$. Values followed by the same letter were not significantly different $(p \leq 0.05$, HSD).

Table 3. Mean effect of the accession and exogenous putrescine (Put), spermidine (Spd), and spermine (Spm) on shoot regeneration and ploidy analysis of the regenerants from protoplast-derived callus colonies of Brassica oleracea L. var. capitata. The values for the percentage of regeneration are the means $\pm \operatorname{SE}(n=20)$. Values followed by the same letter were not significantly different $(p \leq 0.05$, HSD).

\begin{tabular}{|c|c|c|c|c|c|c|}
\hline \multirow{2}{*}{ Factor } & \multicolumn{2}{|c|}{ Total (n) } & \multirow{2}{*}{$\begin{array}{c}\text { Regeneration } \\
(\%)\end{array}$} & \multicolumn{3}{|c|}{ Ploidy of Regenerants $(n)$} \\
\hline & Calli & Shoots & & Analyzed & $2 x$ & $4 x$ \\
\hline \multicolumn{7}{|l|}{ Accession: } \\
\hline Sława z Gołębiewa & 1823 & 85 & $4.7 \pm 1.2^{\mathrm{a}}$ & 71 & 70 & 1 \\
\hline L203 & 1221 & 14 & $1.1 \pm 0.5^{\mathrm{c}}$ & 12 & 12 & 0 \\
\hline LLM & 1572 & 44 & $2.8 \pm 0.6^{\mathrm{b}}$ & 41 & 39 & 2 \\
\hline \multicolumn{7}{|l|}{ Polyamines $(\mu \mathrm{M})$ : } \\
\hline Control & 1025 & 24 & $2.3 \pm 0.6^{\mathrm{bcd}}$ & 22 & 21 & 1 \\
\hline Put 10 & 500 & 65 & $13.0 \pm 0.7^{\mathrm{a}}$ & 52 & 51 & 1 \\
\hline Put 20 & 510 & 13 & $2.5 \pm 0.8^{\mathrm{bcd}}$ & 12 & 12 & 0 \\
\hline Put 40 & 363 & 3 & $0.8 \pm 0.1^{\mathrm{cd}}$ & 3 & 3 & 0 \\
\hline Spd 10 & 400 & 5 & $1.3 \pm 0.6^{\mathrm{cd}}$ & 4 & 4 & 0 \\
\hline Spd 20 & 436 & 18 & $4.1 \pm 1.0^{b}$ & 18 & 17 & 1 \\
\hline Spd 40 & 347 & 12 & $3.5 \pm 1.1^{b c}$ & 10 & 10 & 0 \\
\hline Spm 10 & 307 & 3 & $1.0 \pm 0.3^{\mathrm{cd}}$ & 3 & 3 & 0 \\
\hline Spm 20 & 358 & 0 & $0.0 \pm 0.0^{\mathrm{d}}$ & 0 & 0 & 0 \\
\hline Spm 40 & 370 & 0 & $0.0 \pm 0.0^{\mathrm{d}}$ & 0 & 0 & 0 \\
\hline
\end{tabular}



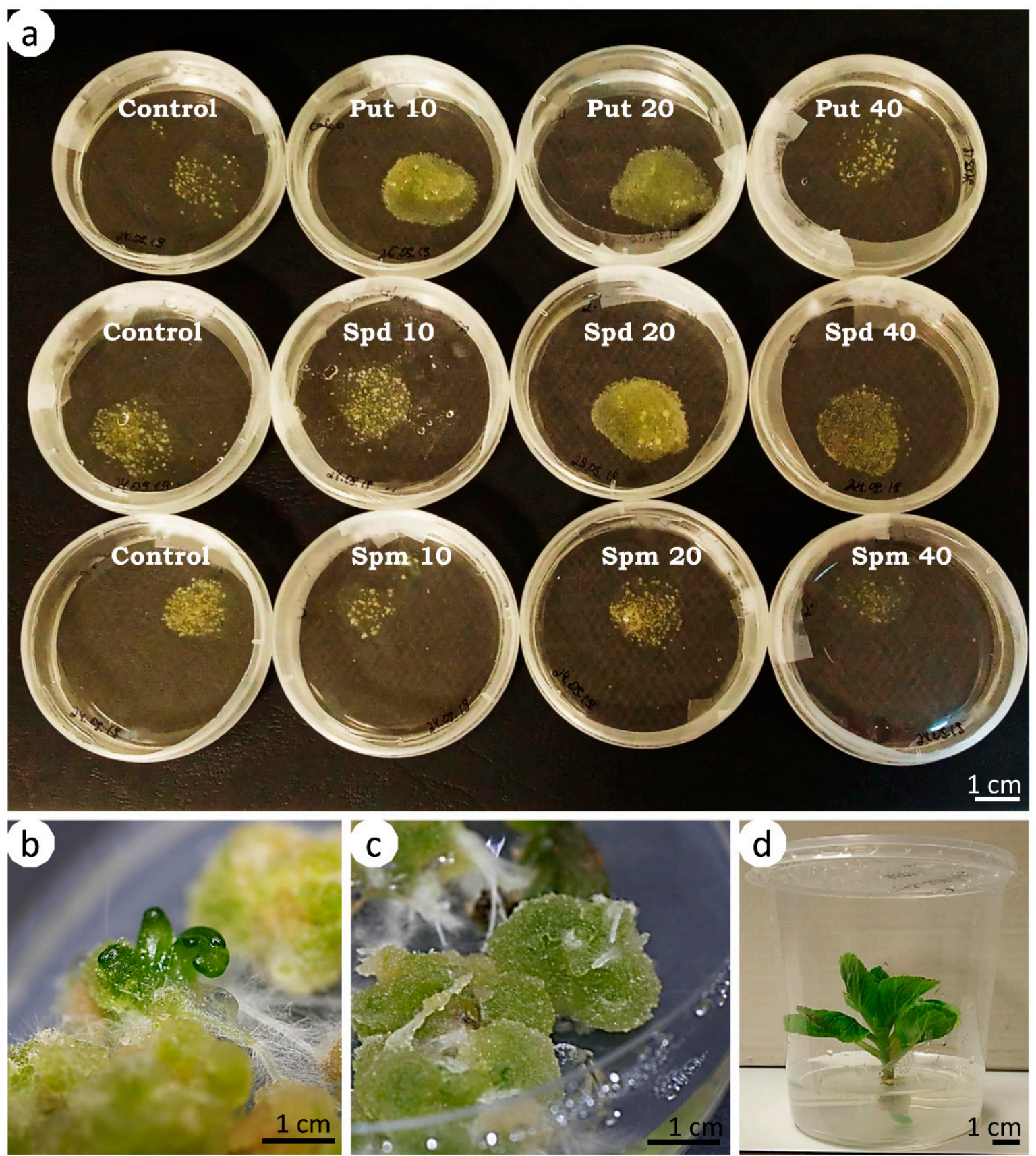

Figure 6. Callus development and organogenesis from the protoplast-derived cells of Brassica oleracea L. var. capitata treated with putrescine (Put), spermidine (Spd), and spermine (Spm) and the control. The alginate layers were overgrown with calli tissue of different intensities, depending on the type of polyamine and its concentrations (in $\mu \mathrm{M})$ and the control (a); shoot (b) and root (c) organogenesis from protoplast-derived cells; regenerated shoot (d). Scale bar: $1 \mathrm{~cm}$.

Supplementation of the liquid culture medium in the tested PAs affected the shoot regeneration (Table 3). The highest shoot regeneration $(13.0 \%)$, exceeding the control $(2.3 \%)$, was observed from protoplast-derived callus colonies that developed on the medium with $10 \mu \mathrm{M}$ of Put. An increased concentration of Put in the liquid culture phase negatively affected the regeneration process, and the shoot regeneration was much lower (0.8-2.5\%). Regeneration from the protoplast-derived calli that developed on the media with all tested concentrations of Spd was similar to the control. The frequency of shoot regeneration from calli that developed on the medium with $10 \mu \mathrm{M}$ Spm was $1.0 \%$. Shoots were not regenerated from calli that developed on the media supplemented with higher concentrations (20 and $40 \mu \mathrm{M})$ of Spm. 
The analysis of the interaction of the accession and exogenously applied PAs showed that for two out of the three tested accessions, the highest percentage of regenerated shoots was observed from protoplast-derived callus colonies that developed on the medium supplemented with $10 \mu \mathrm{M}$ Put (Figure 8 ). The frequencies varied from $12.2 \%$ in the breeding line LLM up to $20.8 \%$ in cv. "Sława z Gołębiewa," which exceeded the control combinations (2.1 and $3.4 \%$, respectively). In both accessions, higher concentrations $(20$ and $40 \mu \mathrm{M})$ of Put significantly decreased the shoot regeneration. In the breeding line L203, the shoot regeneration was observed only from cultures that were treated with Put (1.8-3.7\%) and Spd $(0.6-2.8 \%)$; however, it was similar to the control combination $(0.8 \%)$.

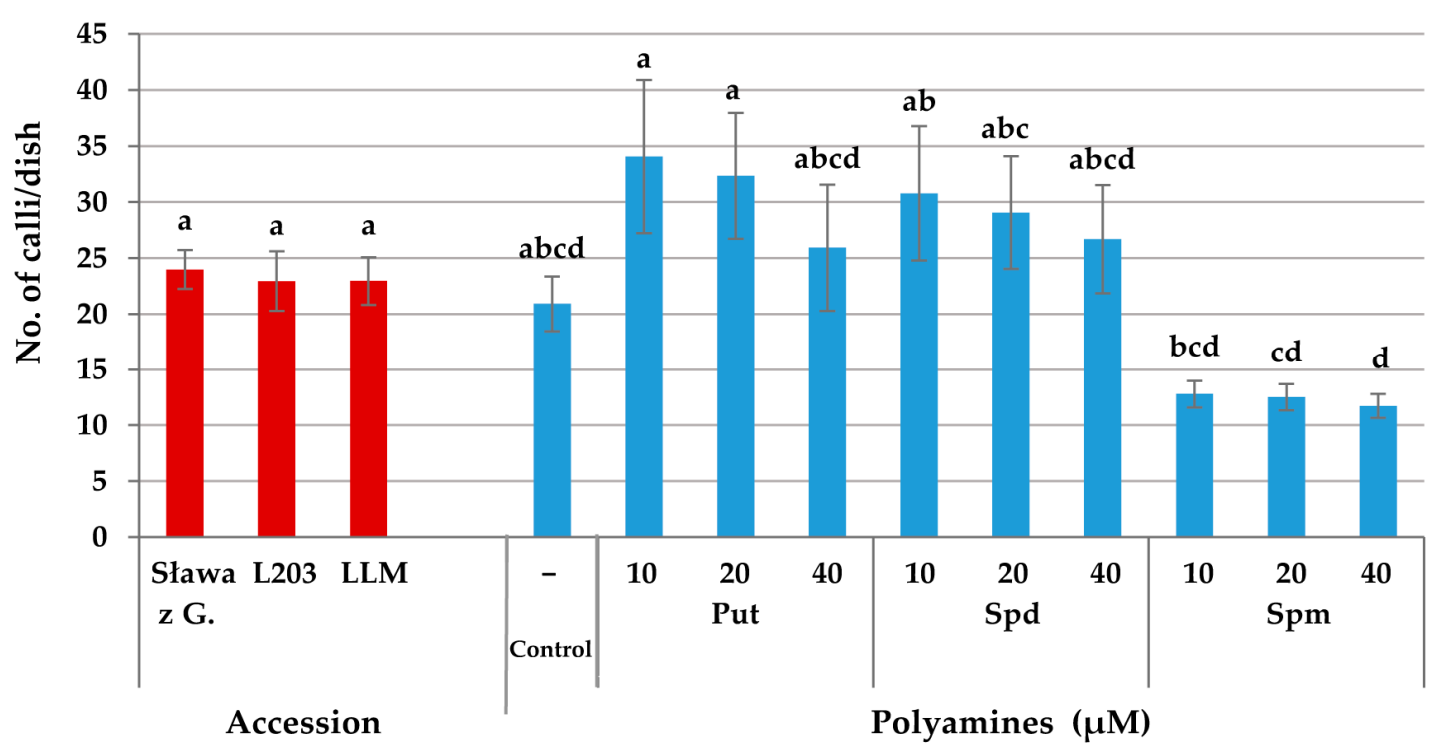

Figure 7. Effect of the accession and exogenous putrescine (Put), spermidine (Spd), and spermine (Spm) on the callus production from the protoplast-derived cells of Brassica oleracea L. var. capitata. The bars represent means $\pm \mathrm{SE}(n=20)$. The red and blue bars should be considered separately. Values followed by the same letter were not significantly different $(p \leq 0.05$, HSD).

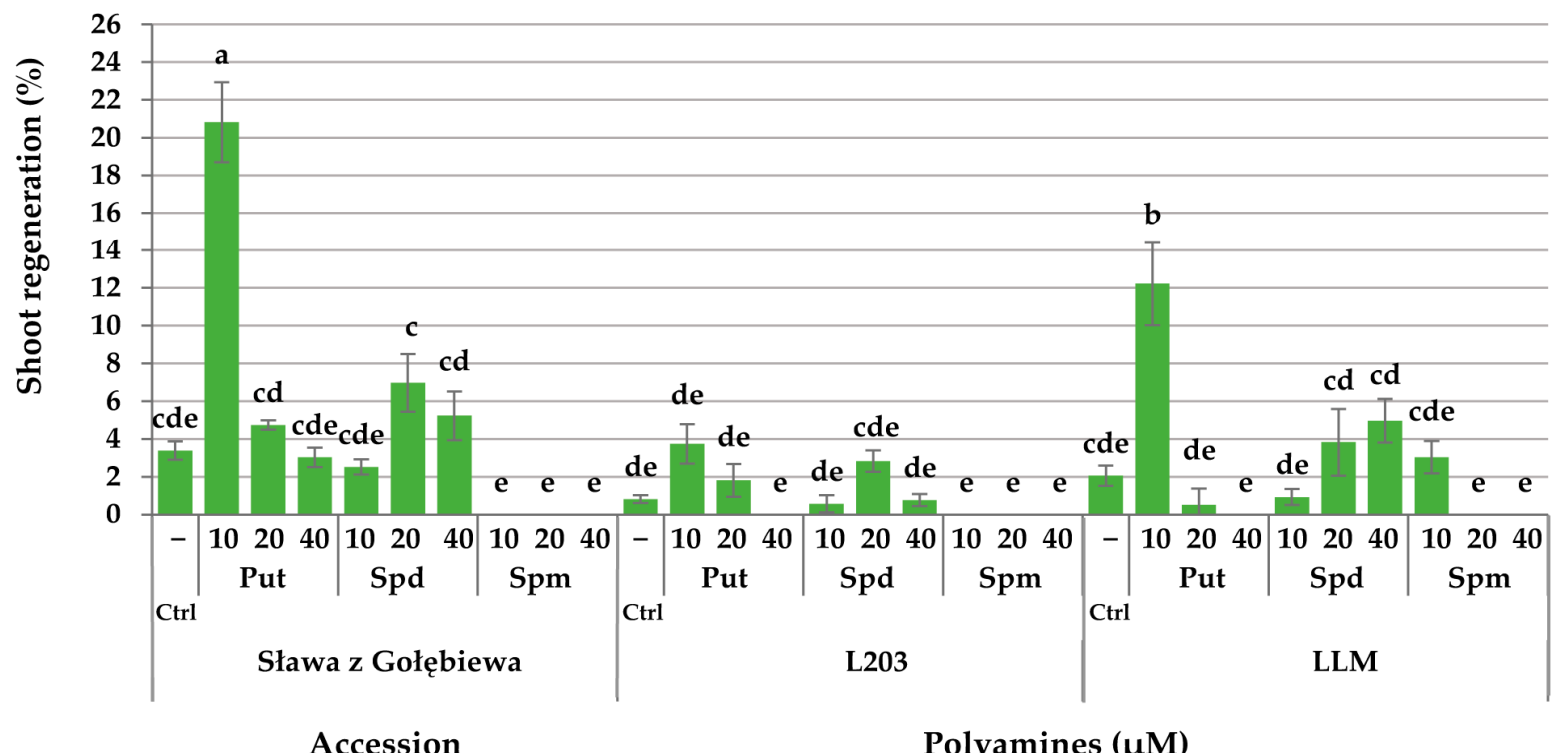

Figure 8. Interaction of the accession and exogenous putrescine (Put), spermidine (Spd), and spermine (Spm) on the shoot regeneration from protoplast-derived callus colonies of Brassica oleracea L. var. capitata. The bars represent the means $\pm \mathrm{SE}(n=20)$. Values followed by the same letter were not significantly different $(p \leq 0.05, \mathrm{HSD})$. Ctrl signifies the PA-free control media. 
Flow cytometry showed that the majority of the regenerants were diploids; however, three plants among the 124 tested were tetraploids (Table 3). Those were regenerated from protoplast-derived calli that developed on the control medium and media supplemented with $10 \mu \mathrm{M}$ Put and $20 \mu \mathrm{M}$ Spd.

\section{Discussion}

\subsection{ROS Detection in Polyamine-Treated Protoplasts}

Here, for the first time, we applied PAs to B. oleracea L. var. capitata hypocotyl protoplasts to analyze whether an exogenous supply affected protoplast-derived cell proliferation and the regeneration process. First, the effect of exogenous PAs on ROS accumulation was studied. In nature, $\mathrm{ROS}$ (i.e., ${ }^{1} \mathrm{O}_{2},{ }^{3} \mathrm{O}_{2}, \mathrm{O}_{2} \cdot-{ }^{\cdot}, \mathrm{H}_{2} \mathrm{O}_{2}, \mathrm{OH}, \mathrm{NO}, \mathrm{ONOO}^{-}$) are inevitably produced in higher plant cells during normal metabolism and have a role as signaling molecules [46]. Their production is enhanced during stress [46-49]. The integrity of cells is seriously endangered if ROS cannot be controlled by scavenging molecules and other repair mechanisms within the cell [50]. The procedures of enzymatic protoplast isolation induce osmotic stress [51], as well as an immediate oxidative burst [35], with mitochondria and chloroplasts acting as main ROS producers [52]. Our results confirmed these findings, as we detected ROS accumulation in isolated protoplasts in the untreated control combination. The analysis of the results from PA-treated cultures revealed that the ROS accumulation in the protoplasts subjected to treatment with Put and Spd was lower compared to the protoplasts in the PA-free controls. In contrast, the ROS accumulation in the Spm-treated cultures was higher than in the control cultures. Moreover, our study showed that oxidative stress, as detected by $\mathrm{H}_{2}$ DCFDA, lasted even up to $48 \mathrm{~h}$ after the protoplast release from donor tissues and decreased during culturing. It was proven that intracellular ROS are released and scavenged immediately at the time of cellular degradation $[46,49]$. $\mathrm{H}_{2}$ DCFDA was reported to react with peroxynitrite $\left(\mathrm{ONOO}^{-}\right)$, the reaction product of nitric oxide and superoxide, as well as with intracellular $\mathrm{H}_{2} \mathrm{O}_{2}[45,50]$. It is likely that these types of more stable intracellular ROS were responsible for the observed signals. The location of the fluorescent signals over time showed that scavenging machinery acted more rapidly in chloroplasts than in the cytoplasm of the cultured cells.

\subsection{Viability of Polyamine-Treated Protoplasts}

In plants, PAs are considered as biogenic molecules with an impact on several diverse biological processes [53], although their importance for maintaining viability has not been fully elucidated. PA-dependent decreases in RNase and protease activity and their effect on the decrease in ethylene production and inhibition of senescence were reported [53,54]. Moreover, PAs regulate cation exchange, protect membrane potential, and control the intracellular $\mathrm{pH}[14,16]$. These processes affect cell viability within tissues. Considering the single-cell culture model, the viability of protoplast-derived cells seems to be tightly associated with stress, which is an effect of the isolation process and culture establishment. As shown in this study, exogenous PAs provide significant protection against oxidative damage, which can explain the observed decrease in the ROS accumulation of PA-treated protoplasts and the effect on maintaining the viability of cultured cells.

\subsection{Mitotic Activity of Polyamine-Treated Cells}

In our study, PAs were present in the culture media only for the first ten days, as the medium used for the replacement was PA-free. This showed that a short-lasting treatment with PAs was sufficient for the stimulation of the development of protoplasts of B. oleracea L. var. capitata to the levels increasing the control cultures. This was possibly the result of the positive effect of exogenous PAs on both maintaining the cell viability and their action on the progression of the cell cycle. In Beta vulgaris L. protoplast cultures, exogenous Put and Spd stimulated cell division only in the responsive genotype, while Spm was most suitable for the recalcitrant accession [55]. In our study, the most efficient stimulation of cell division was recorded after supplementation of the culture media with 
Put and Spd, where this tendency was observed in all three accessions. However, the overall frequency of cell division was lower in the tested breeding lines compared to the commercial cultivar "Sława z Gołebiewa." Such results showed the genotypic effect on cell proliferation, which was commonly observed in protoplast cultures of B. oleracea and other species $[4,7,8,10,48]$. Considering the aforementioned studies, the different responses might also be related to the different levels of endogenous PAs between the tested accessions $[14,56]$, which might further affect their response after an exogenous PA application. Although the endogenous PA levels were not evaluated in this study, studies in other species, i.e., Cucumis sativus L. [18] and Picea abies L. [57], showed that exogenous PAs might affect the level of endogenous PAs; therefore, it cannot be excluded that at the single-cell level (protoplast culture), similar processes could occur, ultimately leading to the more effective response to stress during isolation and culture establishment.

Majewska-Sawka et al. [55] supplemented protoplast cultures of Beta vulgaris L. with Put, Spd, and Spm in combination with other plant growth regulators (PGRs) (NAA, BA) and alone. The PA supplementation alone had a detrimental effect on the cultured protoplasts; however, in combination with PGRs, they produced a favorable plating efficiency. Similar results were observed in our study, as our standard media for culturing $B$. oleracea L. protoplasts was supplemented with 2,4-D and zeatin and PAs. Such results indicate that the best effect for the stimulation of cell division from protoplast-derived cells could be achieved via the simultaneous application of PAs and PGRs. Although many plant cellular processes are also regulated with plant hormones, little is understood about the interaction between plant hormones and biogenic amines. Transcriptomic data evidenced a complex relationship between the PAs and their role in the biosynthesis and signaling pathways of plant hormones [53].

\subsection{Regeneration from Polyamine-Treated Protoplast Cultures}

B. oleracea $\mathrm{L}$. is a very diverse group, and the intraspecific variation within this group for in vitro regeneration from different explants has been well recognized [11,58]. The recalcitrance of $B$. oleracea L.to regenerate shoots from protoplast cultures also remains problematic, as the effects of the genotype often override the efforts to improve protocols for plant regeneration $[7,8,11]$. In this study, the effect of exogenous PAs on the production of calli from protoplast-derived cells was observed. The highest callus production was observed from protoplast-derived cultures supplemented with Put. The regeneration ability was associated with green, compact calli with an organized structure. Whitish, loose calli and browning calli had no regeneration potency. Recently, a study on Oryza sativa L. subsp. indica [59] showed that exogenous Put caused a marked improvement in rice callus growth and a reduction in callus browning. Moreover, the content of endogenous Put in the browning callus was lower than that of normal proliferating calli.

There are no reports describing the role of exogenous PAs on regeneration from protoplast cultures in B. oleracea L. Here, the indirect effect of exogenous PAs on the regeneration from protoplast cultures in B. oleracea L. var. capitata was observed, which was reflected in the higher number of shoots produced from protoplasts cultured on the media supplemented with PAs at the liquid culture stage and transferred for regeneration onto solid PA-free media. This led to the conclusion that PAs had the potential to stimulate sustained cell divisions and were also important for its maintenance. The mitotic divisions stimulated by PAs were sustained even after transferring protoplast-derived callus tissue to the solid PA-free regeneration medium, which resulted in a higher percentage of organogenesis compared to the untreated controls. Considering the role of specific PAs on the stimulation of the regeneration in protoplast cultures, the best response in our study for B. oleracea L. var. capitata was observed after the application of Put and Spd, while Spm was not effective. There have been no comparative studies in other species and the regeneration from protoplast cultures treated with PAs was not reported [51,60] or not achieved [55]; however, exogenous Put was reported to enhance plant regeneration from calli in Picea abies L. [61]. Spd was the most effective for shoot regeneration in Cucumis sativus L. [62] shot 
tip explants, or Withania somnifera L. [63] nodal explants. Put is the precursor of Spd and Spm, and spermidine synthase (SPDS, EC 2.5.1.16) catalyzes Spd formation from Put [14]. Spd is considered a nitrogen source that enhances shoot differentiation in cotyledonary node explants of soybean (Glycine max L.) [64]. Conversely, in Vitis vinifer L. a, the addition of Spm to the culture medium significantly promoted plantlet development and increased the embryo germination rate [26]. This indicated that the addition of appropriate concentrations of PA to the culture medium could significantly increase the efficiency of in vitro regeneration.

Flow cytometric analyses of regenerants from PA-treated cultures and the control showed that the majority (98\%) of plants were diploids; however, single plants were identified as tetraploids. Although it was reported that applying exogenous PAs can regulate nucleic acid synthesis and protein translation [57], the observed polyploidization was likely not the effect of the exogenous PAs. There was no relationship between the polyploidization and PA supplementation, as there were few tetraploids and they were also observed in the control. During isolation, the protoplasts are able to fuse spontaneously [65], which is the most probable cause of polyploidization observed in this study.

\section{Conclusions}

This is the first report showing the effect of exogenous PAs on Brassica oleracea L. var. capitata protoplast cultures. The incorporation of PAs into the culture media can enhance the development of protoplasts, depending on the type of applied PA and its concentration. The positive effect of Put and Spd on maintaining the viability of protoplast-derived cells was demonstrated, which is likely connected with their role in alleviating the oxidative stress experienced by cells during isolation and culture establishment. Put- and Spd-treated cabbage protoplasts produced less ROS than the PA-free controls. The higher viability rates of cells in the culture ensured the higher chances to enter and progress into the cell cycle and undergo divisions. It was demonstrated that the mitotic activity of Brassica oleracea $\mathrm{L}$. var. capitata protoplasts could be increased by the short-term (10 days) supplementation of culture media with PAs, with Put being the most effective. Finally, the supplementation of liquid culture media with PAs had an indirect effect on shoot regeneration from protoplastderived callus colonies. This indicated that the response of B. oleracea L. protoplasts to exogenous PAs was complex, suggesting multiple bioactivities. It was demonstrated that PAs were critical at the initial stages of the protoplast culture, during the stage of entering the cell cycle and cycle progression. PAs have a role in sustaining cell divisions and cell growth, which further leads to organ formation and its emergence.

In these studies, we observed an indirect effect of PAs on the regeneration from protoplast cultures. Further research will investigate the direct effect of PAs on this process by supplementing the regeneration media with PAs.

Author Contributions: Conceptualization, A.K. and A.A.; methodology, A.K.; software, A.K.; validation, A.K.; formal analysis, A.K.; investigation, A.K.; resources, A.K.; writing-original draft preparation, A.K.; writing-review and editing, A.K. and A.A.; visualization, A.K.; supervision, A.K.; funding acquisition, A.K. and A.A. All authors have read and agreed to the published version of the manuscript.

Funding: This research project was financed from statutory funds provided by the Ministry of Science and Higher Education of the Republic of Poland to the Faculty of Biotechnology and Horticulture at the University of Agriculture in Krakow (DS3500).

Data Availability Statement: The data presented in this study are available on request from the corresponding author.

Acknowledgments: The authors thank Marta Solarz, Florentyna Bara, and Katarzyna Rolka for their excellent work with the tissue cultures and Alicja Białachowska from Kutnowska Hodowla Buraka Cukrowego KHBC Straszków, Poland for the ploidy analyses of the regenerants.

Conflicts of Interest: The authors declare no conflict of interest. 


\section{References}

1. Branca, F.; Cartea, M.E. Brassica. In Wild Crop Relatives: Genomic and Breeding Resources, Oilseeds; Kole, C., Ed.; Springer: Berlin/Heidelberg, Germany, 2011; pp. 17-36. [CrossRef]

2. Li, Z.S.; Liu, Y.M.; Fang, Z.Y.; Yang, L.M.; Zhuang, M.; Zhang, Y.Y.; Lv, H.H. Development and identification of anti-cancer component of sulforaphane in developmental stages of broccoli (Brassica oleracea var. italica L.). J. Food Nutr. Res. 2016, 4, 490-497. [CrossRef]

3. Andrade, F.H.; Sala, R.G.; Pontaroli, A.C.; Leon, A.; Castro, S. Integration of biotechnology, plant breeding and crop physiology. Dealing with complex interactions from a physiological perspective. In Crop Physiology. Applications for Genetic Improvement and Agronomy; Sadras, V.O., Calderini, D.F., Eds.; Academic Press: Cambridge, MA, USA, 2015; pp. 267-276. [CrossRef]

4. Davey, M.R.; Anthony, P.; Power, J.B.; Lowe, K.C. Plant protoplasts: Status and biotechnological perspectives. Biotechnol. Adv. 2005, 23, 131-171. [CrossRef] [PubMed]

5. Eeckhaut, T.; Lakshmanan, P.S.; Deryckere, D.; Van Bockstaele, E.; Huylenbroeck, J.V. Progress in plant protoplast research. Planta 2013, 238, 991-1003. [CrossRef]

6. Ren, J.P.; Dickson, M.H.; Earle, E.D. Improved resistance to bacterial soft rot by protoplast fusion between Brassica rapa and B. oleracea. Theor. Appl. Genet. 2000, 100, 810-819. [CrossRef]

7. Kiełkowska, A.; Adamus, A. An alginate-layer technique for culture of Brassica oleracea L. protoplasts. In Vitr. Cell Dev. Biol. Plant 2012, 48, 265-273. [CrossRef] [PubMed]

8. Kiełkowska, A.; Adamus, A. Embedding in filter sterilized alginate enhances Brassica oleracea L. protoplast culture. Acta Biol. Crac. Ser. Bot. 2014, 56, 20-26. [CrossRef]

9. Lian, Y.; Lin, G.; Zheng, Q. Tri-parental protoplast fusion of Brassica species to produce somatic hybrids with high genetic and phenotypic variability. Indian J. Gen. Plant. Breed. 2015, 75, 497-505. [CrossRef]

10. Kirti, P.B.; Bhat, S.R.; Kumar, V.D.; Parkash, S.; Chopra, V.L. A simple protocol for regenerating mesophyll protoplasts of vegetable Brassicas. J. Plant. Biochem. Biotechnol. 2001, 10, 49-51. [CrossRef]

11. Holme, I.B.; Torp, A.M.; Hansen, L.N.; Andersen, S.B. Quantitative trait loci affecting plant regeneration from protoplasts of Brassica oleracea. Theor. Appl. Genet. 2004, 108, 1513-1520. [CrossRef] [PubMed]

12. Wang, X.J.; Ikeguchi, Y.; McCloskey, D.E.; Nelson, P.; Pegg, A.E. Spermine synthesis is required for normal viability, growth, and fertility in the mouse. J. Biol. Chem. 2004, 279, 51370-51375. [CrossRef]

13. De Oliveira, L.F.; Navarro, B.V.; Cerruti, G.V.; Elbl, P.; Minocha, R.; Minocha, S.C.; Dos Santos, A.L.W.; Floh, E.I.S. Polyamine- and amino acid-related metabolism: The roles of arginine and ornithine are associated with the embryogenic potential. Plant Cell Physiol. 2018, 59, 1084-1098. [CrossRef]

14. Chen, D.; Shao, Q.; Yin, L.; Younis, A.; Zheng, B. Polyamine function in plants: Metabolism, regulation on development, and roles in abiotic stress responses. Front. Plant. Sci. 2019, 9, 1945. [CrossRef]

15. Michael, A.J. Biosynthesis of polyamines and polyamine-containing molecules. Biochem. J. 2016, 473, 2315-2329. [CrossRef]

16. Romero, F.M.; Maiale, S.J.; Rossi, F.R.; Marina, M.; Ruíz, O.A.; Gárriz, A. Polyamine metabolism responses to biotic and abiotic stress. In Polyamines. Methods in Molecular Biology; Alcázar, R., Tiburcio, A., Eds.; Humana Press: New York, NY, USA, 2018; Volume 1694, pp. 37-49. [CrossRef]

17. Alcázar, R.; Altabella, T.; Marco, F.; Bortolotti, C.; Reymond, M.; Koncz, C.; Carrasco, P.; Tiburcio, A.F. Polyamines molecules with regulatory functions in plant abiotic stress tolerance. Planta 2010, 231, 1237-1249. [CrossRef]

18. Wu, J.; Shu, S.; Li, C.; Sun, J.; Guo, S. Spermidine-mediated hydrogen peroxide signaling enhances the antioxidant capacity of salt-stressed cucumber roots. Plant. Physiol. Biochem. 2018, 128, 152-162. [CrossRef] [PubMed]

19. Bais, H.; Ravishankar, G. Role of polyamines in the ontogeny of plants and their biotechnological applications. Plant. Cell Tiss. Organ. Cult. 2002, 69, 1-34. [CrossRef]

20. Minguet, E.G.; Vera-Sirera, F.; Marina, A.; Carbonell, J.; Blazquez, M.A. Evolutionary diversification in polyamine biosynthesis. Mol. Biol. Evol. 2008, 25, 2119-2128. [CrossRef] [PubMed]

21. Kiełkowska, A.; Dziurka, M. Changes in polyamine pattern mediates sex differentiation and unisexual flower development in monoecious cucumber (Cucumis sativus L.). Physiol Plant. 2021, 171, 48-65. [CrossRef] [PubMed]

22. Chi, G.-L.; Lin, W.-S.; Lee, J.E.E.; Pua, E.-C. Role of polyamines on de novo shoot morphogenesis from cotyledons of Brassica campestris ssp. pekinensis (Lour) Olsson in vitro. Plant. Cell Rep. 1994, 13, 323-329. [CrossRef] [PubMed]

23. Pua, E.C.; Deng, X.; Koh, A.T.C. Genotypic variability of de novo shoot morphogenesis of Brassica oleracea in vitro in response to ethylene inhibitors and putrescine. J. Plant. Physiol. 1999, 155, 598-605. [CrossRef]

24. Fienberg, A.A.; Choi, J.H.; Lubich, W.P.; Sung, Z.R. Developmental regulation of polyamine metabolism in growth and differentiation of carrot culture. Planta 1984, 162, 532-539. [CrossRef] [PubMed]

25. Minocha, S.C.; Minocha, R. Role of polyamines in somatic embryogenesis. In Biotechnology in Agriculture and Forestry, Somatic Embryogenesis and Synthetic Seed; Bajaj, Y.P.S., Ed.; Springer: Berlin, Germany, 1995; Volume 30, pp. 53-70. [CrossRef]

26. Faure, O.; Mengoli, M.; Nougarede, A.; Bagni, N. Polyamine pattern and biosynthesis in zygotic and somatic embryo stages of Vitis vinifera. J. Plant. Physiol. 1991, 138, 545-549. [CrossRef]

27. Garrido, D.; Chibi, F.; Matilla, A. Polyamines in the induction of Nicotiana tabacum pollen embryogenesis by starvation. J. Plant. Physiol. 1995, 145, 731-735. [CrossRef] 
28. Martinez, L.E.; Aguero, C.B.; Lopez, M.E.; Galmarini, C.R. Improvement of in vitro gynogenesis induction in onion (Allium cepa L.) using polyamines. Plant. Sci. 2000, 156, 221-226. [CrossRef]

29. Geoffriau, E.; Kahane, R.; Martin-Tanguy, J. Polyamines are involved in the gynogenesis process in onion. Physiol. Plant. 2006, 127, 119-129. [CrossRef]

30. Calheiros, M.B.P.; Vieira, L.G.E.; Fuentes, S.R.L. Effects of exogenous polyamines on direct somatic embryogenesis in coffee. Rev. Bras. Fisiol. Veg. 1994, 6, 109-114.

31. Galston, A.W.; Kaur-Sawhney, R. Polyamines as endogenous growth regulators. In Plant Hormones. Physiology, Biochemistry and Molecular Biology; Davies, P.J., Ed.; Kluwer Academic Publishing: Dordrecht, Germany, 1995; pp. 158-178. [CrossRef]

32. Taie, H.A.A.; Seif El-Yazal, M.A.; Ahmed, S.M.A.; Rady, M.R. Polyamines modulate growth, antioxidant activity, and genomic DNA in heavy metal-stressed wheat plant. Environ. Sci Pollut Res. 2019, 26, 22338-22350. [CrossRef]

33. Huhtinen, O.; Honkanen, J.; Simola, L.K. Ornithine- and putrescine-supported divisions and cell colony formation in leaf protoplasts of alders (Alnus Glutinosa and A. Incana). Plant. Sci. Lett. 1982, 28, 3-9. [CrossRef]

34. Papadakis, A.; Paschalidis, K.; Roubelakis-Angelakis, K. Biosynthesis profile and endogenous titers of polyamines differ in totipotent and recalcitrant plant protoplasts. Physiol. Plant. 2005, 125, 10-20. [CrossRef]

35. Papadakis, A.K.; Roubelakis-Angelakis, K.A. Oxidative stress could be responsible for the recalcitrance of plant protoplast. Plant. Physiol. Biochem. 2002, 40,549-559. [CrossRef]

36. Bidabadi, S.S.; Jain, S.M. Cellular, molecular and physiological aspects of in vitro plant regeneration. Plants 2020, 9, 702. [CrossRef]

37. Kiełkowska, A.; Adamus, A. Peptide growth factor phytosulfokine- $\alpha$ stimulates cell divisions and enhances regeneration from $B$. oleracea var. capitata L. protoplast culture. J. Plant. Growth Regul. 2019, 38, 931-944. [CrossRef]

38. Kiełkowska, A.; Adamus, A. Early studies on the effect of peptide growth factor phytosulfokine- $\alpha$ on Brassica oleracea var. capitata L. protoplasts. Acta Soc. Bot. Pol. 2017, 86, 3558. [CrossRef]

39. Murashige, T.; Skoog, F. A revised medium for rapid growth and bioassays with tobacco tissue cultures. Physiol. Plant. 1962, 15, 473-497. [CrossRef]

40. Menczel, L.; Nagy, F.; Kiss, Z.R.; Maliga, P. Streptomycin resistant and sensitive hybrids of Nicotiana tabacum + Nicotiana knightiana: Correlation of resistance to N. tabacum plastids. Theor. Appl. Genet. 1981, 59, 191-195. [CrossRef] [PubMed]

41. Kao, K.N.; Michayluk, M.R. Nutritional requirements for growth of Vicia hajastana cells and protoplasts at a very low population density in liquid media. Planta 1975, 126, 105-110. [CrossRef]

42. Gamborg, O.L.; Miller, R.A.; Ojima, K. Nutrient requirements of suspension cultures of soybean root cells. Exp. Cell Res. 1968, 50, 151-158. [CrossRef]

43. Damm, B.; Willmitzer, L. Regeneration of fertile plants from protoplasts of different Arabidopsis thaliana genotypes. Mol. Gen. Genet. 1988, 213, 15-20. [CrossRef]

44. Kiełkowska, A.; Adamus, A.; Baranski, R. Haploid and doubled haploid plant production in carrot using induced parthenogenesis and ovule excision in vitro. In Plant Cell Culture Protocols. Methods in Molecular Biology; Loyola-Vargas, V., Ochoa-Alejo, N., Eds.; Humana Press: New York, NY, USA, 2018; Volume 1815, pp. 301-315. [CrossRef]

45. Rota, C.; Chignell, C.F.; Mason, R.P. Evidence for free radical formation during the oxidation of $2^{\prime}-7^{\prime}$-dichlorofluorescin to the fluorescent dye $2^{\prime}-7^{\prime}$-dichlorofluorescein by horseradish peroxidase: Possible implications for oxidative stress measurements. Free Radic. Biol. Med. 1999, 27, 873-881. [CrossRef]

46. Chen, Y.; Yuan, B.; Wei, Z.; Chen, X.; Chen, Y.; Qiu, N. The ion homeostasis and ROS scavenging responses in 'NL895' poplar plantlet organs under in vitro salinity stress. In Vitr. Cell. Dev. Biol.-Plant 2018, 54, 318-331. [CrossRef]

47. Kiełkowska, A. Allium cepa root meristem cells under osmotic (sorbitol) and salt ( $\mathrm{NaCl}$ ) stress in vitro. Acta Bot. Croat. 2017, 76, 146-153. [CrossRef]

48. Kiełkowska, A.; Grzebelus, E.; Lis-Krzyścin, A.; Maćkowska, K. Application of the salt stress to the protoplast cultures of the carrot (Daucus carota L.) and evaluation of the response of regenerants to soil salinity. Plant. Cell Tiss. Organ. Cult. 2019, 137, 379-395. [CrossRef]

49. Fehér, A.; Otvös, K.; Pasternak, T.P.; Szandtner, A.P. The involvement of reactive oxygen species (ROS) in the cell cycle activation (G(0)-to-G(1) transition) of plant cells. Plant. Signal. Behav. 2008, 3, 823-826. [CrossRef] [PubMed]

50. Kristiansen, K.A.; Jensen, P.E.; Møller, I.M.; Schulz, A. Monitoring reactive oxygen species formation and localisation in living cells by use of the fluorescent probe CM-H(2)DCFDA and confocal laser microscopy. Physiol Plant. 2009, 136, 369-383. [CrossRef] [PubMed]

51. Watanabe, M.; Kawasaki, H.; Itho, Y.; Watanabe, Y. Senescence development of Brassica napus leaf protoplast during isolation and subsequent culture. J. Plant. Physiol. 1998, 152, 487-493. [CrossRef]

52. Tiew, T.W.; Sheahan, M.B.; Rose, R.J. Peroxisomes contribute to reactive oxygen species homeostasis and cell division induction in Arabidopsis protoplasts. Front. Plant. Sci. 2015, 6, 658. [CrossRef]

53. Anwar, R.; Mattoo, A.K.; Handa, A.K. Polyamine interactions with plant hormones: Crosstalk at several levels. In Polyamines; Kusano, T., Suzuki, H., Eds.; Springer: Tokyo, Japan, 2015; pp. 267-302. [CrossRef]

54. Tiburcio, A.F.; Altabella, T.; Bitrián, M.; Alcázar, R. The roles of polyamines during the lifespan of plants: From development to stress. Planta 2014, 240, 1-18. [CrossRef]

55. Majewska-Sawka, A.; Niklas, A.; Jażdżewska, E. The effect of polyamines on the development of sugar beet protoplasts. Biol. Plant. 1997, 39, 561-567. [CrossRef] 
56. Kumar, V.; Giridhar, P.; Chandrashekar, A.; Al, E. Polyamines influence morphogenesis and caffeine biosynthesis in vitro cultures of Coffea canephora. Acta Physiol. Plant. 2008, 30, 217-223. [CrossRef]

57. Vondráková, Z.; Eliášová, K.; Vágner, M.; Al, E. Exogenous putrescine affects endogenous polyamine levels and the development of Picea abies somatic embryos. Plant. Growth Regul. 2015, 75, 405-414. [CrossRef]

58. Park, M.H.; Nishimura, K.; Zanelli, C.F.; Valentini, S.R. Functional significance of eIF5A and its hypusine modification in eukaryotes. Amino Acids 2010, 38, 491-500. [CrossRef]

59. Tan, Y.; Hu, W.; Xu, X.; Zhou, J.; Wang, C.; Liu, X.; Cheng, G. Polyamine plays a role in subculture growth of in vitro callus of Indica Rice. Acta Biol. Crac. s. Bot. 2017, 59, 105-112. [CrossRef]

60. Watanabe, M.; Hanamoto, T.; Watanabe, Y. Changes in the activities of ammonia assimilation enzymes during early culture of Brassica napus leaf protoplasts. Tech. Bul. Fac. Hort. Chiba Univ. 1997, 51, 7-13. [CrossRef]

61. Tang, W.; Newton, R.J.; Outhavong, V. Exogenously added polyamines recover browning tissues into normal callus cultures and improve plant regeneration in pine. Physiol. Plant. 2004, 122, 386-395. [CrossRef]

62. Vasudevan, A.; Selvaraj, N.; Ganapathi, A.; Kasthurirengan, S.; Ramesh-Anbazhagan, V.; Manickavasagam, M.; Choi, C. Leucine and spermidine enhance shoot differentiation in cucumber (Cucumis sativus L.). In Vitr. Cell Dev. Biol. Plant. 2008, 44, 300-306. [CrossRef]

63. Sivanandhan, G.; Mariashibu, T.S.; Arun, M.; Rajesh, M.; Kasthurirengan, S.; Selvaraj, N.; Ganapathi, A. The effect of polyamines on the efficiency of multiplication and rooting of Withania somnifera (L.) Dunal and content of some withanolides in obtained plants. Acta Physiol. Plant. 2011, 33, 2279-2288. [CrossRef]

64. Arun, M.; Subramanyam, K.; Theboral, J.; Ganapathi, A.; Manickavasagam, M. Optimized shoot regeneration for Indian soybean: The influence of exogenous polyamines. Plant. Cell Tiss. Organ. Cult. 2014, 117, 305-309. [CrossRef]

65. Ye, G.; Earle, E.D. Effect of cellulases on spontaneous fusion of maize protoplasts. Plant. Cell Rep. 1991, 10, 213-216. [CrossRef] 